\title{
Effects of Nitrogenous Fertilization and some Insecticides on the Natural Enemies of Transgenic Bt Cotton Pests
}

\author{
Mamoun Fadlelmawla ${ }^{1} \oplus$, Azhari Abdelbagi ${ }^{2} \oplus$, Abd Elaziz Ishag ${ }^{2,3 \bowtie} \odot$, Ahmed Hammad ${ }^{2} \oplus$ \& Jang-Hyun Hur ${ }^{3} \oplus$ \\ 1. University of Kassala, Department of Crop Protection, Kassala, Sudan. 2. University of Khartoum, Department of Crop Protection, \\ Khartoum North, 13314, Shambat, Sudan. 3. Kangwon National University, Department of Biological Environment, Chuncheon, \\ Gangwon-do, Republic of Korea.
}

\section{EntomoBrasilis 14: e948 (2021)}

\section{Edited by:}

William Costa Rodrigues

\section{Article History:}

Received: 30.v.2021

Accepted: 01.ix.2021

Published: 01.x.2021

Corresponding author:

Abd Elaziz Ishag

円a.aziz30@gmail.com

Funding agencies:

\& Ministry of Higher Education and Scientific Research, Sudan

\begin{abstract}
Field assessment of integrated management of BT cotton pests was carried out in two consecutive seasons; 2016/2017 and 2017/2018 in the experimental research farm of the Kassala University, Sudan. Four insecticides (imidacloprid, abamectin, profenofos, and lufenuron) from different chemical groups and with a different mode of action and three levels (43.81 kgha-1, $87.62 \mathrm{kgha}^{-}$ 1 , and $131.43 \mathrm{kgha}^{-1}$ ) of soil-applied nitrogen were tested in the IPM package. Insecticides were applied at the recommended doses. A total of 7 weekly counts of prevailing natural enemies [Chrysoperla carnea (Stephens) and Aenasius bambawalei Hayat] were carried out for 4 weeks before spraying and 3 weeks post spraying starting the $3^{\text {rd }}$ week from spraying. Results indicated that nitrogen level exerted no significant effects on the populations of prevailing natural enemies; C. carnea and A. bambawalei. Based on average post spray counts and percentage reduction over the control, all insecticide treatments significantly reduced the population of the natural enemies. Imidacloprid and profenofos exerted the highest reduction of C. carnea population followed by abamectin and lufenuron (56.03, $48.25,07.78$ and $06.61 \%$ respectively) in the first season, while profenofos, imidacloprid, lufenuron, and abamectin induced the highest reductions $(55.94,45.05,17.57$ and $17.33 \%$ respectively) in the second season. On the other hand, reductions in A. bambawalei population (abundant in season 1 only) followed the order; imidacloprid, lufenuron, abmectin, and profenofos (03.95, 02.63, 202.63, and $01.32 \%$, respectively). Interactions between nitrogen fertilization and insecticide were not significant as measured by the population of prevailing natural enemies.
\end{abstract}

Keywords: Bt Cotton; Natural Enemies; Nitrogen; Insecticides Sudan.
( otton (Gossypium hirsutum $\mathrm{L}$ ) is considered the leading fiber crop, grown in more than 80 countries (GIRI et al. 2016). More than 1,300 species of insects were reported as pests of cotton worldwide; among them are bollworms and sap-sucking pests (MATTHEWs \& TUNSTALL 1994). Bt toxins produced by transgenic cotton can effectively control lepidopterous species but fail to control sap-sucking pests (Hofs et al. 2004; Sharma \& PAMPAPTHy 2006). While there is a decrease in the status of bollworms; the sap feeders, viz. aphids, jassids, mirids, and mealybugs are currently emerged as serious pests in Bt cotton (VeNNILA 2008). The fact that modified insect-resistant Bt cotton received far fewer doses of insecticides may consequently favour the increase in the population of sucking insect pests (Men et al. 2005).

Further higher densities of Bt cotton responds to higher doses of nitrogen by producing significantly higher yields (BHARATHI et al. 2012) but they provide congenial substratum for the growth and development of sucking pests throughout the growing period (ANusHA et al. 2017). Further such higher nitrogen doses were also reported to reduce the plant resistance and consequently increase the occurrence of serious insect herbivores such as leafhoppers, whiteflies, and thrips (AHmed et al. 2007) and subsequently increase the crop damage (GE et al. 2003).

The combination of nitrogen fertilization with insecticides treatments were found to decrease the population of sucking pests and increase the yield of Bt cotton (FADLELMAWLA et al. 2020), but they could destroy the beneficial natural enemies and non-target arthropods (NARANJo 2001; FeRnANDES et al. 2010) in most cropping systems and subsequently, cause pest resurgence or outbreak of secondary pests. The indiscriminate use of insecticides may promote resistance to the resurgence of sap-sucking pests (RoHINI et al. 2012) and urged the search for safe alternatives to synthetic chemicals (Munoza et al. 2013).

Natural enemies of insects play an important role in regulating agricultural pests under normal conditions. Therefore, utilization of natural enemies in biological control (through importation, augmentation, or conservation) comprises an important component of many integrated pest management programs. Among effective natural enemies used in IPM programs is Chrysoperla carnea (Stephens) (Chrysopidae, Neuroptera) and Aenasius bambawalei Hayat (Hymenoptera: Encyrtidae). C. carnea is a predator on many soft-bodied insects (PRINCIPI \& CANARD 1984; ChaKRABORTY \& Korat 2010). SCOPEs (1969) reported that the $C$. carnea possesses a wide range of hosts such as whiteflies, thrips, mealy bugs, aphids, besides the eggs of different arthropods. It has significant potential for commercialization and uses against a variety of crop pests in combination with other strategies of insect pest management (CHAKRABORTY \& KORAT 2010).

In laboratory experiments, МотA et al. (2012) found that the biology and development of Chrysoperla externa Hagen (Neuroptera: Chrysopidae) larvae fed on Aphis gossypii Glover (Hemiptera: Aphididae) reared on leaves of Bt cotton were not affected by Cry1Ac toxin, possibly because these aphids 
do not tend to accumulate the Bt-toxin.

Aenasius bambawalei has been identified and reported as a solitary endoparasitoid on Phenacoccus solenopsis Tinsley (Hemiptera: Pseudococcidae). A. bambawalei was found to parasitize cotton mealy bug in Pakistan (MAHMOOD 2008) and in India (TANwAR et al. 2008). It is the only dominant and aggressive parasitoid reported so far, responsible for the decline of mealy bug after its initial establishment (RISHI et al. 2009). Adult females parasitize the third instar nymphs of $P$. solenopsis (AsHFAQ et al. 2010) and kill the host before maturity. The parasitization resulted in reddish-brown mealy bug mummies easily distinguishable from the healthy colony (PRASAD et al. 2011). The parasitization efficiency of the parasitoid from field-collected mealy bugs was $57.2 \%$ whereas, under laboratory conditions, it was $60.6 \%$ (RISHI et al. 2009) and up to $80 \%$ under favorable conditions (VENNILA 2010).

The high economic losses of Bt cotton caused by sap-sucking pests and the expected negative environmental impacts of the chemical control initiated our interest to develop an a simple IPM package for the management of these pests. The specific objectives of this study were to evaluate the negative impact of the designed IPM package on the natural abundance of the prevailing natural enemies (C. carnea and A. bambawalei). The designed package included three levels of nitrogenous fertilization and four insecticides (imidacloprid, abamectin, profenofos, and lufenuron) from different chemical groups. The efficacy of the IPM package on the abundance of sapsucking insects, cottonseed yield, and net profit was covered in another study (FAdLelmawla et al. 2020).

\section{MATERIAL AND METHODS}

Location, treatments, and experimental design. The current study was carried out for two consecutive seasons; 2016/2017 and 2017/2018 in the experimental research farm (15.3261, 35.5895) of the Faculty of Agriculture and Natural Resources of Kassala University, Sudan. Split-plot design was adopted with three doses of nitrogen (as urea) as the main factor with five insecticide treatments (including the control) as sub-factors (sub-plots). Each treatment was replicated three times. The plot area was $4 \times 5 \mathrm{~m}^{2}$ each divided into six ridges. Treatments were randomly distributed at the two levels.

Sowing and cultural practices. The source of cotton seeds (Sini 1 cultivar) was Halfa Algadidah Agric. Corporation. Seeds were sown on August $5^{\text {th }}$ in both seasons (2016/2017 and 2017/2018). Cultural practices followed the recommendation of Halfa Algadidah Agric. Corporation except for the nitrogen fertilization, which was done at three levels (as the main factor), before the $3^{\text {rd }}$ irrigation (one month from sowing). Insecticides were sprayed on November $5^{\text {th }}$ (three months after sowing).

Nitrogen fertilization (factor I). Urea $\left(46 \% \mathrm{~N}_{2}\right)$ was evenly distributed in all plots and immediately followed by irrigation. Three levels [N1(43.81), N2(87.62), and N3(131.43) kg/ha] of urea were used.

Table 1. The insecticides used in the study.

Insecticide

\begin{tabular}{|c|c|c|c|c|}
\hline \multicolumn{2}{|c|}{ Insecticide } & \multirow{2}{*}{ Group } & \multirow{2}{*}{ Dose (g ai/ha) } & \multirow{2}{*}{ Application rate (L/ha) } \\
\hline Common name & Trade name & & & \\
\hline Lufenuron & Match 5\%EC & Chitin synthesis inhibitor (IGR) & 47.50 & 0.950 \\
\hline Profenofos & Selecron 720EC & Organophosphate & 720.00 & 1.000 \\
\hline Abamectin & Vertemic 18EC & Avermectin (Microbial) & 09.72 & 0.540 \\
\hline Imidacloprid & Confidor 200EC & Neonicotinoid & 26.00 & 0.130 \\
\hline
\end{tabular}

Insecticide's treatments (factor II). Four types of insecticides from different chemical groups (imidacloprid, abamectin, profenofos, and lufenuron) were sprayed by pneumatic knapsack sprayer, at spray volume of $100 \mathrm{~L}$ per 0.42 ha. The source of the applied insecticides is the local agents in Sudan. Dosage and application rates were shown in Table1.

Counts of natural enemies. All counts of natural enemies were recorded weekly for seven weeks. Counts were done at 6 am and continued for few minutes after sunrise. Counts were taken from plants in the inner four ridges. Four prespray counts (from the $11^{\text {th }}$ of October to the $1^{\text {st }}$ of November) and three post-spray counts (from the $8^{\text {th }}$ to the $22^{\text {nd }}$ of November) were carried out in the two seasons.

Eggs of $C$. Carnea per 100 leaves were counted in each plot. The mealy bug ( $A$. bambawalei) infestation was estimated by the number of mealy bug mummies per 10 randomly selected plants in each plot.

Data, transformation, and analysis. The counts of natural enemies ( $C$. carnea and $A$. bambawalei) were transformed to $(X+0.5)^{1 / 2}$ before statistical analysis. Transformed data were analyzed by the Analysis of variance (ANOVA) and means were separated by Tukey's honestly significant difference test.

\section{RESULTS AND DISCUSSION}

Effect of nitrogenous fertilization on the natural enemies. The aim of the study is to assess the impact of the designed IPM package on the natural enemies (C. carnea and A. bambawalei) abundant in the experimental plots during the two seasons. The abundance of the C. carnea was assessed by the number of eggs while that of $A$. bambawalei was assessed by the number of infested mealy bug mummies. C. carnea eggs were found throughout the various weeks in both seasons while the parasitoid $A$. bambawalei was found in season one only. The absence of the latter in season two might be explained by the unavailability of the host (mealy bug) in the experimental plots although was found parasitizing mealy bug in adjacent fallow land weeds (specially Abutilon) but never spread to the cotton in that season due to the lack of suitable transport mechanisms (animals, humans etc.) during that season. The occurrence of the two natural enemies, $C$. carnea eggs and $A$. bambawalei, was not significantly affected by the applied nitrogen fertilizer and there is no direct association between the level of the nitrogen and the population of the two natural enemies ( $p=0.05$; Table 2; Figure 1). However, there is a slight dose-related increase in the counts of $C$. carnea eggs observable during the $2^{\text {nd }}$ and $3^{\text {rd }}$ week while the increase in the counts of infested mealy bug mummies was noticeable during the $3^{\text {rd }}$ and $4^{\text {th }}$ week (Table 2; Figure1). This may be elucidated by the fact that natural enemies do not feed directly on plants, however; they might indirectly be influenced by nitrogen fertilization through insect host (Couture et al. 2010; Garratt et al. 2010). Nitrogen is one of the most frequently used fertilizers in agricultural production systems. Its application potentially exerts variety of bottom-up effects, which can significantly alter tritrophic interactions through different mechanisms (CHEN et al. 2010). 
Table 2. Effects of the nitrogenous fertilization on the natural abundance of Chrysoperla carnea eggs

\begin{tabular}{|c|c|c|c|c|c|c|c|c|}
\hline \multirow{2}{*}{ Seasons } & \multirow{2}{*}{ Treatment } & \multicolumn{4}{|c|}{ Average of pre-spray counts } & \multicolumn{3}{|c|}{ Average of post-spray counts } \\
\hline & & Week 1 & week 2 & week 3 & week 4 & week 5 & week 6 & week 7 \\
\hline \multirow{7}{*}{1} & N1 & $1.47 \mathrm{a}$ & $2.53 \mathrm{a}$ & $3.60 \mathrm{a}$ & $4.33 \mathrm{a}$ & $2.67 \mathrm{a}$ & $2.07 \mathrm{a}$ & $1.66 \mathrm{a}$ \\
\hline & N2 & $1.07 \mathrm{a}$ & $2.80 \mathrm{a}$ & $3.80 \mathrm{a}$ & $3.60 \mathrm{a}$ & $2.60 \mathrm{a}$ & $2.00 \mathrm{a}$ & $1.73 \mathrm{a}$ \\
\hline & N3 & $1.33 \mathrm{a}$ & $2.87 \mathrm{a}$ & $3.87 \mathrm{a}$ & $3.53 \mathrm{a}$ & $2.60 \mathrm{a}$ & $2.00 \mathrm{a}$ & $1.80 \mathrm{a}$ \\
\hline & Standard error \pm & 0.32 & 0.42 & 0.41 & 0.33 & 0.38 & 0.27 & 0.33 \\
\hline & LSD & ns & ns & ns & ns & ns & ns & ns \\
\hline & GM & 1.29 & 2.73 & 3.76 & 3.82 & 2.62 & 2.02 & 1.73 \\
\hline & RSD\% & 9.77 & 9.37 & 4.57 & 13.32 & 6.00 & 8.67 & 8.03 \\
\hline \multirow{9}{*}{ II } & & \multicolumn{4}{|c|}{ Average of pre-spray counts } & \multicolumn{3}{|c|}{ Average of post-spray counts } \\
\hline & Heatmenc & week 1 & week 2 & week 3 & week 4 & week 5 & week 6 & week 7 \\
\hline & N1 & $1.64 \mathrm{a}$ & $2.60 \mathrm{a}$ & $3.60 \mathrm{a}$ & $3.73 \mathrm{a}$ & $3.53 \mathrm{a}$ & $3.20 \mathrm{a}$ & $2.88 \mathrm{a}$ \\
\hline & N2 & $1.23 \mathrm{a}$ & $2.80 \mathrm{a}$ & $3.67 \mathrm{a}$ & $2.60 \mathrm{a}$ & $3.27 \mathrm{a}$ & $2.60 \mathrm{a}$ & $2.53 \mathrm{a}$ \\
\hline & N3 & $1.48 \mathrm{a}$ & $2.87 \mathrm{a}$ & $3.75 \mathrm{a}$ & $2.75 \mathrm{a}$ & $3.00 \mathrm{a}$ & $3.00 \mathrm{a}$ & $2.87 \mathrm{a}$ \\
\hline & Standard error \pm & 0.23 & 0.41 & 0.41 & 0.52 & 0.17 & 0.41 & 0.50 \\
\hline & LSD & ns & ns & ns & ns & ns & ns & ns \\
\hline & General mean & 1.45 & 2.76 & 3.67 & 2.94 & 3.27 & 2.93 & 2.76 \\
\hline & RSD $\%$ & 6.11 & 5.80 & 6.33 & 6.80 & 10.93 & 7.60 & 10.35 \\
\hline
\end{tabular}

N1, N2 and N3 = levels of nitrogen doses. LSD = least significant difference. RSD = relative standard deviation. ns = not significant.

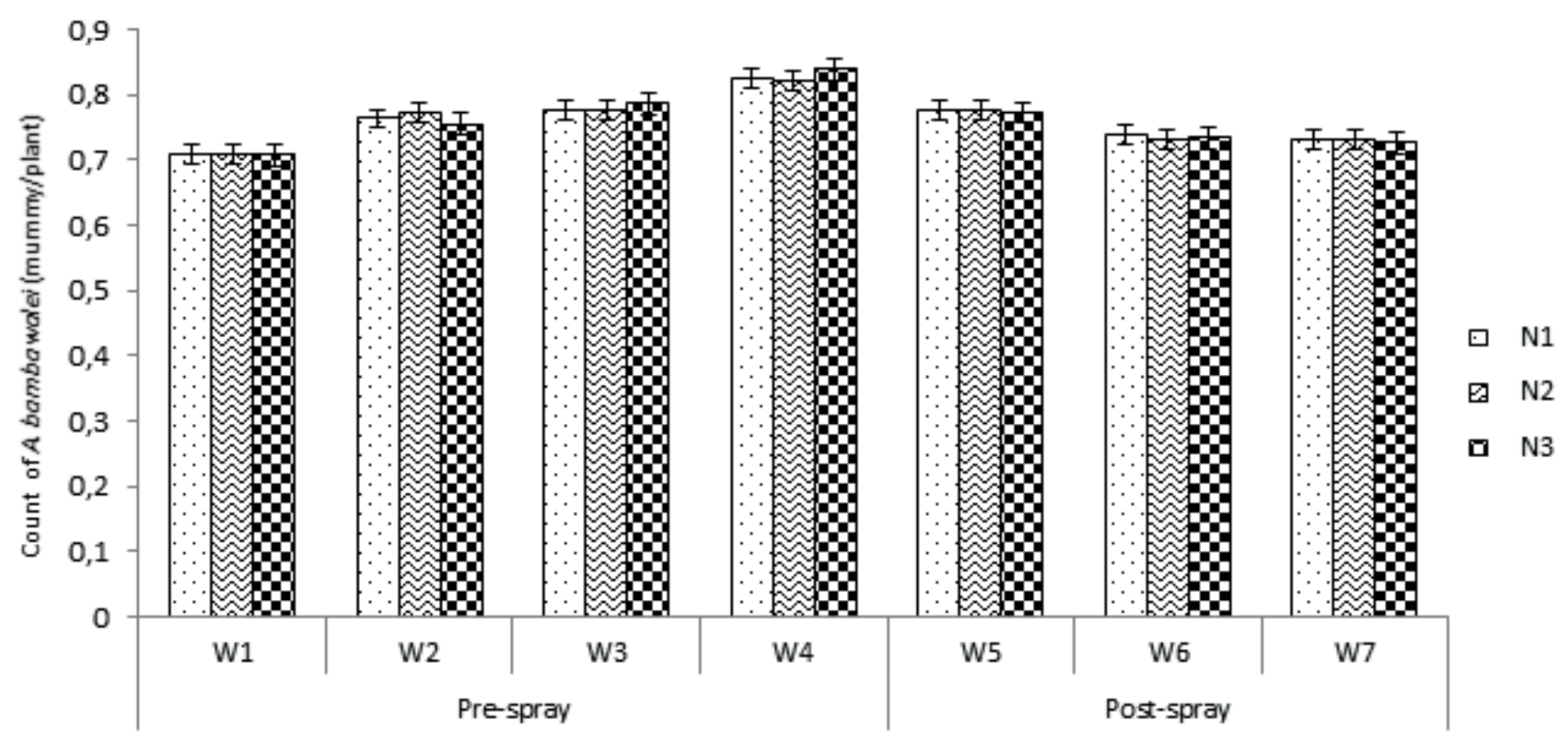

Vertical bars represent \pm the SE

Figure 1. Pre and post-spray count of A. bambawalei (mummy/plant) pre and post-spray in season 1.

AsIImwe et al. (2016) stated that plant quality can influence the impact of natural enemies. Improving the nutritional value of host-plant enhanced the development and fertility of some herbivorous insects (AWMACK \& LEATHER 2002), which enhances also the performance and population density of some predators and parasitoids (HUNTER 2003). Generally, plant quality influences the population dynamics of the insect through changes in their fertility, existence, distribution, competition, and natural enemy induced death (WALKER et al. 2008; ZHu et al. 2020). So, alterations in the quality of host plant may indirectly affect natural enemies through the effects on their prey (Giles et al. 2002; HARVEY et al. 2003). ZHu et al. (2020) reported that the nitrogen application to rice plants prolonged the development of Anagrus flaveolus, increased wing size, decreased female fecundity, and decreased the parasitism by reducing the searching efficiency of $A$. flaveolus. Nitrogen has profound effects on natural enemy efficiency and increases the dependence on insecticides (ZHU et al. 2020). The differences between authors reporting significant indirect effects of nitrogen fertilization on natural enemies might be explained by differences in the strain of the pest or natural enemies studied.

Effects of the insecticides on the abundance of the natural enemies. Results of pre-spray counts (Table3) indicated no significant differences in the abundance of C. carnea eggs in various experiment plots. Counts of the eggs were relatively high in season II compared to season I. Imidacloprid and profenofos exerted the highest significant reduction in the counts of $C$. carnea eggs (Table 3 ) throughout the three post spray counts. There is no significant difference between these insecticides in the two seasons however both are significantly different from other treatments. These results agree with the findings of many authors; GANDHI et al. 
Table 3. Impact of the applied insecticides on the average of natural abundance of Chrysoperla carnea eggs.

\begin{tabular}{|c|c|c|c|c|c|c|c|}
\hline \multirow{3}{*}{ Seasons } & \multirow{3}{*}{ Treatment } & \multirow{3}{*}{ Pre-spray means } & \multicolumn{3}{|c|}{ Average of post-spray counts } & \multirow{3}{*}{$\begin{array}{c}\text { Average of } \\
\text { post-spray } \\
\text { counts }\end{array}$} & \multirow{3}{*}{$\begin{array}{l}\text { Reduction } \\
\text { (\%) }\end{array}$} \\
\hline & & & & Days & & & \\
\hline & & & 3 & 10 & 17 & & \\
\hline \multirow{9}{*}{1} & Lufenuron & $4.11 \mathrm{a}$ & $2.67 a$ & $2.00 \mathrm{a}$ & $2.52 \mathrm{ab}$ & $2.40 a$ & 06.61 \\
\hline & Profonofos & $4.22 \mathrm{a}$ & $1.00 \mathrm{~b}$ & $1.44 \mathrm{~b}$ & $1.56 b$ & $1.33 b$ & 48.25 \\
\hline & Abamectin & $3.33 \mathrm{a}$ & $2.67 \mathrm{a}$ & $2.00 \mathrm{a}$ & $2.44 a b$ & $2.37 a$ & 07.78 \\
\hline & Imidacloprid & $4.44 \mathrm{a}$ & $1.00 \mathrm{~b}$ & $0.99 c$ & $1.40 \mathrm{~b}$ & $1.13 b$ & 56.03 \\
\hline & Control & $3.00 \mathrm{a}$ & $2.78 \mathrm{a}$ & $2.22 \mathrm{a}$ & $2.70 a$ & $2.57 \mathrm{a}$ & - \\
\hline & Standard error \pm & 0.41 & 0.25 & 0.17 & 0.23 & 0.18 & - \\
\hline & LSD & ns & $0.74 * * *$ & $0.51 * * *$ & $0.66 * * \star$ & $0.50 * * \star$ & - \\
\hline & General mean & 3.82 & 2.02 & 1.73 & 1.73 & 2.13 & - \\
\hline & RSD $\%$ & 13.32 & 6.00 & 8.67 & 8.03 & 14.63 & - \\
\hline \multirow{12}{*}{ II } & \multicolumn{5}{|c|}{ Average of post-spray counts } & \multirow{3}{*}{$\begin{array}{c}\text { Average of } \\
\text { post-spray } \\
\text { counts }\end{array}$} & \multirow{3}{*}{$\begin{array}{l}\text { Reduction } \\
\text { (\%) }\end{array}$} \\
\hline & \multirow[t]{2}{*}{ Treatment } & \multirow[t]{2}{*}{ Pre-spray means } & \multicolumn{3}{|c|}{ Days } & & \\
\hline & & & 3 & 10 & 17 & & \\
\hline & Lufenuron & $3.91 \mathrm{a}$ & $3.11 \mathrm{~b}$ & $3.56 \mathrm{a}$ & $3.33 a$ & $3.33 \mathrm{~b}$ & 17.57 \\
\hline & Profonofos & $3.22 \mathrm{a}$ & $2.11 \mathrm{c}$ & $1.36 \mathrm{c}$ & $1.86 \mathrm{~b}$ & $1.78 \mathrm{c}$ & 55.94 \\
\hline & Abamectin & $3.84 \mathrm{a}$ & $3.44 \mathrm{~b}$ & $3.22 \mathrm{a}$ & $3.37 \mathrm{a}$ & $3.34 \mathrm{ab}$ & 17.33 \\
\hline & Imidacloprid & $4.22 \mathrm{a}$ & $2.44 \mathrm{bc}$ & $1.89 \mathrm{~b}$ & $2.33 \mathrm{~b}$ & $2.22 \mathrm{c}$ & 45.05 \\
\hline & Control & $2.67 a$ & $3.56 \mathrm{a}$ & $3.78 \mathrm{a}$ & $4.04 \mathrm{a}$ & $4.04 \mathrm{a}$ & - \\
\hline & Standard error \pm & 0.281 & 0.358 & 0.290 & 0.310 & 0.2 & - \\
\hline & LSD & ns & $0.781 *$ & $0.823 * *$ & $0.780 * \star$ & $0.67 * \star *$ & - \\
\hline & General mean & 2.94 & 2.93 & 2.67 & 2.99 & 2.99 & - \\
\hline & RSD\% & 6.80 & 22.36 & 27.84 & 11.38 & 11.94 & - \\
\hline
\end{tabular}

LSD = least significant difference. RSD = relative standard deviation. ns = not significant. Significant at* $(0.05), * *(0.01), * \star *(0.001)$

(2005) and BRUNner et al. (2001) who found that imidacloprid is toxic to the green lacewing predator, C. carnea under laboratory conditions, while BOUENO \& REITAS (2004) found abamectin is innocuous and lufenurom is toxic to the eggs and larvae of Chrysoperla externa under laboratory conditions. Abamectin, lufenuron were not significantly differ from the untreated set in most post-spray counts and not significantly different from each other. This result agrees with Moura et al. (2012) who found abamectin slightly harmful to C. externa $1^{\text {st }}$ instar larvae and in contrast harmless to the $2^{\text {nd }}$ instar larvae under laboratory conditions. Based on the accumulated post spray mean of counts and the percentage reduction, the insecticide hazards to $C$. carnea eggs can be ranked as follows; imidacloprid, profenofos, abamectin, and lufenuron, in season 1 and profenofos, imidacloprid, lufenuron, and abamectin in season 2. Similar to effect of the designed IPM package on Bt cotton sucking pests (FADLELMAWLA et al. 2020) there is no significant interactions between nitrogen and insecticide treatments measured by the count of $C$. carnea eggs, at $p=0.05$.

Aenasius bambawalei was abundant in season I only (Table 4) and this may be explained by the absence of its main host in Bt Cotton during that season. There are no significant differences in the parasitoid counts (measured by the number of infested mealy bug mummies) between the various experimental units in both pre and post-spray counts except imidacloprid treatments during the second post-spray counts (after 10 days) (Table 4).

Table 4. Impact of the applied insecticides on the natural abundance of Aenasius bambawalei

\begin{tabular}{|c|c|c|c|c|c|c|}
\hline \multirow{3}{*}{ Treatment } & \multirow{3}{*}{ Pre-spray means } & \multicolumn{3}{|c|}{ Average of pre-spray counts } & \multirow{3}{*}{$\begin{array}{c}\text { Accumulated } \\
\text { post-spray } \\
\text { mean }\end{array}$} & \multirow{3}{*}{ Reduction (\%) } \\
\hline & & \multicolumn{3}{|c|}{ Days } & & \\
\hline & & 3 & 10 & 17 & & \\
\hline Lufenuron & $0.84 \mathrm{a}$ & $0.77 \mathrm{a}$ & $0.73 a b$ & $0.73 a$ & $0.74 \mathrm{bc}$ & 02.63 \\
\hline Profonofos & $0.84 \mathrm{a}$ & $0.76 \mathrm{a}$ & $0.74 \mathrm{a}$ & $0.72 \mathrm{a}$ & $0.74 \mathrm{bc}$ & 02.63 \\
\hline Abamectin & $0.84 a$ & $0.78 \mathrm{a}$ & $0.74 \mathrm{a}$ & $0.72 \mathrm{a}$ & $0.75 \mathrm{ab}$ & 01.32 \\
\hline Imidacloprid & $0.86 a$ & $0.76 \mathrm{a}$ & $0.71 b$ & $0.72 \mathrm{a}$ & $0.73 c$ & 03.95 \\
\hline Control & $0.78 a$ & $0.79 a$ & $0.75 \mathrm{a}$ & $0.74 \mathrm{a}$ & $0.76 \mathrm{a}$ & - \\
\hline Standard error \pm & 0.014 & 0.013 & 0.009 & 0.009 & 0.005 & - \\
\hline LSD & ns & ns & 0.026 * & ns & $0.016^{*}$ & - \\
\hline General mean & 0.83 & 0.77 & 0.73 & 0.73 & 0.74 & - \\
\hline RSD $\%$ & 6.33 & 5.00 & 7.17 & 4.43 & 1.15 & - \\
\hline
\end{tabular}

LSD = least significant difference. $R S D=$ relative standard deviation. $\mathrm{ns}=$ not significant. ${ }^{*}=$ significant at 0.05 . 
Being a completely endo-parasitoid (i.e., all developmental stages were found inside the body of the host and therefore protected from direct contact with applied insecticides) may explain the slight percentage reduction in the population of this parasitoid induced by the applied insecticides. The significant reduction in the number of infested mummies observed after 10 days in imidacloprid treated plots may be explained by the toxicity of this insecticide to $A$. bambawalei as reported by BHATT \& JALPA (2018) under laboratory conditions. Based on the accumulated post spray count and the percentage reduction, the hazards of the insecticides to $A$. bambawalei can be ranked as follows imidacloprid, lufenuron, profenofos, and abamectin. Similar to effect of the designed IPM package on Bt cotton sucking pests (FADLELMAWLA et al. 2020) there is no significant interactions between nitrogen and insecticide treatments measured by the count of $A$. bambawalei mumies, at $\mathrm{p}=0.05$.

Nitrogen level exerted no significant effects on the populations of prevailing natural enemies; $C$. carnea and A. bambawalei. All insecticide treatments significantly reduced the population of natural enemies. Imidacloprid and profenofos exerted the highest reduction of C. carnea population followed by abamectin and lufenuron in the first season, while profenofos, imidacloprid, lufenuron, and abamectin induced the highest reductions in the second season. On the other hand reductions in $A$. bambawalei population (abundant in season 1 only) followed the order; imidacloprid, lufenuron, abmectin, and profenofos. Interactions between nitrogenous fertilization and insecticide treatments were not significant as measured by the population of prevailing natural enemies.

\section{ACKNOWLEDGMENTS}

Authors would like to thank Dr. Abdalwahab Hassan Abdalla for his help in the data analysis. The financial support made available by Ministry of Higher Education and Scientific Research, Sudan is greatly acknowledged.

\section{SUPPORT MATERIAL}

1- Table S1. The nitrogen dosages

2- Table S2. Effects of nitrogen fertilization on the abundance of Aenasius bambawalei in season 1

3- Table S3. Counts of Chrysoperla carnea (eggs number) affected by nitrogen*insecticides

4- Table S4. Counts of Aenasius bambawalei (mealybug mummies) affected by nitrogen*insecticides

5- Table S5. C. carnea analysis of variance summary containing the mean square (MS) for the 7-week counts in the two seasons

6- Table S6. A. bambawalei analysis of variance summary containing the mean square (MS) for the 7-week counts in season 1

\section{REFERENCES}

Ahmed, S, S Sabir \& C Mushtaq-ali, 2007. Effect of different doses of nitrogen fertilizer on sucking insect pests of cotton, Gossypium hirsutum. Journal of Agricultural Research, 45: 43-48.

Anusha, S, GMV Prasada Rao \& DV Sai Ram Kumar, 2017. Effect of different nitrogen doses on sucking pests and yield in Bt cotton under unprotected and protected conditions. Journal of Entomology and Zoology Studies, 5: 611-615.

Ashfaq, M, GS Shah, AR Noor, SP Ansari \& S Mansoor, 2010. Report of a parasitic wasp (Hymenoptera: Encyrtidae) parasitizing cotton mealybug (Hemiptera: Pseudococcidae) in Pakistan and use of PCR for estimating parasitism levels. Biocontrol Science and Technology, 20: 625-630. DOI: https://doi.org/10.1080/09583151003693535

Asiimwe, P, P Ellsworth \& S Naranjo, 2016. Natural enemy impacts on Bemisia tabaci (MEAM1) dominate plant quality effects in the cotton system: Top-down effects dominate B. tabaci dynamics. Ecological Entomology, 41: 1-10. DOI: https://doi.org/10.1111/een.12340

Awmack, C \& S Leather, 2002. Host plant quality and fecundity in herbivorous insects. Annual Review of Entomology, 47: 817-844. DOI: https://doi.org/10.1146/annurev. ento.47.091201.145300

Bharathi, S, GMV Prasada Rao, RS Kumari \& V Chengareddy, 2012. Influence of plant geometry and nitrogen levels on performance of cotton hybrids under rainfed conditions in vertisols of Andhra Pradesh. Journal of Cotton Research and Development, 26: 204-206.

Bhatt, NA \& PL Jalpa, 2018. Evaluation of Insecticides against Tobacco Mealy Bug, Phenacoccus solenopsis Tinsley and its Parasitoid, Aenasius bambawalei Hayat under Laboratory Conditions. International Journal of Current Microbiology and Applied Sciences. 7: 2339-2343. DOI: https://doi.org/10.20546/ijcmas.2018.706.279

Boueno, AF\&SReitas, 2004. Effect of the insecticides abamectin and lufenuron on eggs and larvae of Chrysoperla externa under laboratory conditions. BioControl, 49: 277-283. DOI: https://doi.org/10.1023/B:BICO.0000025375.07428.0b

Brunner, JF, JE Dunley, MD Doerr \& ES Beers, 2001. Effect of Pesticides on Colpoclypeusflorus (Hymenoptera: Eulophidae) and Trichogramma platneri (Hymenoptera: Trichogrammatidae), Parasitoids of Leafrollers in Washington. Journal of Economic Entomology, 94: 10751084. DOI: https://doi.org/10.1603/0022-0493-94.5.1075

Chakraborty D \& DM Korat, 2010. Biology of green lacewing, Chrysoperla carnea (Stephens) in middle Gujarat conditions. Karnataka Journal of Agricultural Sciences, 23: 500-502.

Chen Y, JR Ruberson \& D Olson, 2010. Nitrogen fertilization rate affects feeding, larval performance and oviposition preference of the beet armyworm, Spodoptera exigua, on cotton. Entomologia Experimentalis et Applicata, 126: 244-255. DOI: https://doi.org/10.1111/j.15707458.2007.00662.x

Couture, JJ, JS Servi \& RL Lindroth, 2010. Increased nitrogen availability influences predator-prey interactions by altering host-plant quality. Chemoecology, 20: 277-284. DOI: https://doi.org/10.1007/s00049-010-0058-y

Fadlelmawla, MK, AO Abdelbagi, AESA Ishag, AMA Hammad \& J-H Hur, 2020. Effects of nitrogen fertilization and some non-conventional insecticides on sap sucking pests and yield of transgenic Bt cotton in Sudan. International Journal of Tropical Insect Science, 41: 1471-1484. DOI: https://doi.org/10.1007/s42690-020-00345-y

Fernandes FL, I Bacci \& MS Fernandes, 2010. Impact and selectivity of insecticides to predators and parasitoids. EntomoBrasilis, 3: 1-10. DOI: https://doi.org/10.12741/ ebrasilis.v3i1.52

Gandhi, PI, K Gunasekaran, S Poonguzhali, R Anandham, GH Kim, KY Chung \& T Sa, 2005. Laboratory evaluation of relative toxicities of some insecticides against Trichogramma chilonis (Hymenoptera: Trichogrammatidae) and Chrysoperla carnea (Neuroptera: Chrysopidae). Journal of Asia-Pacific Entomology, 8: 381-386. DOI: https://doi.org/10.1016/S1226-8615(08)60267-8

Garratt, MP, SR Leather \& DJ Wright, 2010. Tritrophic effects of organic and conventional fertilisers on a cerealaphid-parasitoid system: Entomologia Experimentalis et Applicata 134: 211-219. DOI: https://doi.org/10.1111/ j.1570-7458.2009.00957.x

Ge, F, X Liu, H Li, X Men \& J Su, 2003. Effect of nitrogen fertilizer on pest population and cotton production]. Ying Yong Sheng Tai Xue Bao. 14: 1735-8. Chinese.

Giles, KL, RD Madden, R Stockland, ME Payton \& JW Dillwith, 2002. Host plants affect predator fitness via the nutritional value of herbivore prey: investigation of a plant-aphid-lady-beetle system: Biocontrol, 47: 1-21. DOI: 
https://doi.org/10.1023/A:1014419623501

Giri, MD, MB Dhonde \& AD Tumbare, 2016. Effect of Split and Foliar Application of Nitrogen on Leaf Nitrogen Concentration and SPAD Index and Photosynthesis in Bt Cotton (Gossypium hirsutum L.). SAARC Journal of Agriculture, 14: 01-11. DOI: https://doi.org/10.3329/sja. v14i2.31239

Harvey, JA, NM van Dam \& R Gols, 2003. Interactions over four trophic levels: food plant quality affects the development of a hyper parasitoid as mediated through a herbivore and its primary parasitoid. Journal of Animal Ecology, 72: 520-531. DOI: https://doi.org/10.1046/j.13652656.2003.00722.x

Hayat, M, 2009. Description of a new species of Aenasius Walker (Hymenoptera: Encyrtidae), parasitoid of the mealybug, Phenacoccus solenopsis Tinsley (Homoptera: Pseudococcidae) in India. Biosystematica, 3: 21-26.

Hofs, JL, A Schoeman \& M Vaissayre, 2004. Effect of Bt cotton on arthropod biodiversity in South African cotton fields. Communications in Agricultural and Applied Biological Sciences, 69: 191-194.

Hunter, MD, 2003. Effects of plant quality on the population ecology of parasitoids. Australian Journal of Entomology, 5: 1-8. DOI: https://doi.org/10.1046/j.14619563.2003.00168.x

Mahmood, R, 2008. Breakthrough in biological control of mealybug. Pakistan Biocontrol News and Information, 29: 38-39.

Matthews, GA \& JP Tunstall, 1994. Insect pests of cotton. C. A. B. International, Wallingford, England.

Men, X, F Ge, CA Edwards \& EN Yardim, 2005. The influence of pesticide applications on Helicoverpa armigera Hubner and sucking pests in transgenic Bt cotton and non-transgenic cotton in China. Crop Protection, 24: 319-324. DOI: https://doi.org/10.1016/j.cropro.2004.08.006

Mota, TA, MG Fernandes, MF de Souza, PRB da Fonseca, JC de Quadros \& SO Kassab, 2012. Tritrofic interactions between Bt cotton plants, the aphid Aphis gossypii Glover, 1827 (Hemiptera: Aphididae), and the predator, Chrysoperla externa (Hagen, 1861) (Neuroptera: Chrysopidae). African Journal of Agricultural Research, 7: 5919-5924. DOI: https://doi.org/10.5897/AJAR12.2056

Moura, AP, GA Carvalho \& M Botton, 2012. Residual effects of pesticides used in integrated apple production on Chrysoperla externa (Hagen) (Neuroptera: Chrysopidae) larvae. ChileanJournal of Agricultural Research, 72:217-223. DOI: https://doi.org/10.4067/s0718-58392012000200009

Munoza, E, C Lamillaa, JC Marin, J Alarconc \& CL Cespedesa, 2013. Antifeedant, insect growth regulatory and insecticidal effects of Calceolaria talcana (Calceolariaceae) on Drosophila melanogaster and Spodoptera frugiperda. Industrial Crops and Products, 42: 137-144. DOI: https://doi.org/10.1016/j.indcrop.2012.05.014
Naranjo, ES, 2001. Conservation and evaluation of natural enemies in IPM systems for Bemisia tabaci. Crop Protection, 20: 835-852. DOI: https://doi.org/10.1016/ S0261-2194(01)00115-6

Prasad, YG, M Prabhakar, G Sreedevi \& M Thirrupathi, 2011. Spatio-temporal dynamics of the parasitoid, Aenasius bambawalei Hayat (Hymenoptera: Encyrtidae) on mealybug, Phenacoccus solenopsis Tinsley in cotton based cropping systems and associated weed flora. Journal of Biological Control, 25: 198-202.

Principi, MM \& M Canard, 1984. Feeding habits. pp. 76-92. In: M. Canard, Y. Seméria and T.R. New (eds) Biology of Chrysopidae. The Hague, W. Junk.

Rishi, K, KR Kranthi, D Monga \& SL JAT, 2009. Natural parasitization of Phenacoccus solenopsis Tinsley (Hemiptera: Pseudococcidae) on cotton by Aenasius bambawalei Hayat (Hymenoptera: Encyrtidae. Journal of Biological Control, 23: 457-460.

Rohini, A, VSD Prasad \& MSV Chalam, 2012. Management of major sucking pests in cotton by insecticides, Annals of Plant Protection Sciences, 20: 102-106.

Scopes, NEA, 1969. The potential of Chrysoperla carnea as a biological control agent of Myzus persicae in glass houses. Annals of Applied Biology, 32: 433-439. DOI: https://doi.org/10.1111/j.1744-7348.1969.tb02892.x

Sharma, HC \& G Pampapathy, 2006. Influence of transgenic cotton on the relative abundance and damage by target and non-target insect pests under different protection regimes in India: Crop Protection, 25: 800-813. DOI: https://doi.org/10.1016/j.cropro.2005.11.002

Tanwar, RK, VK Bhamare, VV Ramamurthy, M Hayat, $\mathrm{P}$ Jeyakumar \& A Singh A, 2008. Record of new parasitoid on mealybug, Phenacoccus solenopsis, Indian Journal of Entomology, 70: 404-405.

Vennila, S, 2008. Pest management for cotton ecosystems or ecosystem management for cotton production, Current Science, 94: 1351-1352.

Vennila, S, VV Ramamurthy, A Deshmukh, DB Pinjarkar, M Agarwal \& PC Pagar, 2010. A treatise on mealybugs of Central Indian cotton production system. Technical Bulletin No. 24, National Centre for Integrated Pest Management, New Delhi. 30-39.

Walker, M, SE Hartley \& TH Jones, 2008. The relative importance of resources and natural enemies in determining herbivore abundance: thistles, tephritids and parasitoids, Journal of Animal Ecology, 77: 1063-1071. DOI: https://doi.org/10.1111/j.1365-2656.2008.01406.x

Zhu, P, X Zheng, X Hongxing, CJ Anne, KL Heong, GM Gurr \& L Zhongxian, 2020. Nitrogen fertilizer promotes the rice pest Nilaparvata lugens via impaired natural enemy, Anagrus flaveolus, performance. Journal of Pest Science, 93: 757766. DOI: https://doi.org/10.1007/s10340-019-01177-7 


\section{SUPPLEMENTARY MATERIALS}

Table S1. The nitrogen dosages.

\begin{tabular}{cccc}
\hline Dose level & Urea (46\%)/feddan & Urea (46\%)/ha & Nitrogen (kg/ha) \\
\hline$N_{1}$ & 40.00 & 95.24 & 43.81 \\
$\mathrm{~N}_{2}$ & 80.00 & 190.48 & 87.62 \\
$\mathrm{~N}_{3}$ & 120.00 & 285.72 & 131.43 \\
\hline
\end{tabular}

Table S2. Effects of nitrogen fertilization on the abundance of Aenasius bambawalei in season 1.

\begin{tabular}{|c|c|c|c|c|c|c|c|}
\hline \multirow{2}{*}{ Treatment } & \multicolumn{4}{|c|}{ Pre-spray } & \multicolumn{3}{|c|}{ Post-spray } \\
\hline & W1 & W2 & W3 & W4 & W5 & W6 & W7 \\
\hline N1 & $0.707 \mathrm{a}$ & $0.763 \mathrm{a}$ & $0.775 \mathrm{a}$ & $0.825 \mathrm{a}$ & $0.775 \mathrm{a}$ & $0.738 a$ & $0.730 \mathrm{a}$ \\
\hline N2 & $0.707 a$ & $0.772 \mathrm{a}$ & $0.777 a$ & $0.822 \mathrm{a}$ & 0.776 a & $0.730 \mathrm{a}$ & $0.730 \mathrm{a}$ \\
\hline N3 & $0.707 a$ & $0.755 \mathrm{a}$ & $0.786 a$ & $0.839 a$ & $0.772 \mathrm{a}$ & $0.734 \mathrm{a}$ & $0.726 a$ \\
\hline SE \pm & 0.000 & 0.013 & 0.012 & 0.014 & 0.010 & 0.004 & 0.008 \\
\hline LSD & ns & ns & ns & ns & ns & ns & ns \\
\hline GM & 0.707 & 0.763 & 0.779 & 0.828 & 0.774 & 0.733 & 0.729 \\
\hline CV\% & 0.00 & 6.80 & 5.95 & 6.33 & 5.00 & 7.17 & 4.43 \\
\hline
\end{tabular}

W1, W2, ...W7 = Weeks of counts. N1, N2 and N3 = levels of nitrogen doses. SE = standard error. LSD = least significant difference. GM = general mean. $\mathrm{CV}=$ coefficient of variation. $\mathrm{ns}=$ not significant. $*, * *$, and $* * *=$ significant

Table S3. Counts of Chrysoperla carnea (eggs number) affected by nitrogen*insecticides.

\begin{tabular}{|c|c|c|c|c|c|c|c|c|c|c|c|c|}
\hline \multicolumn{13}{|c|}{ Season 1} \\
\hline \multirow{2}{*}{ Insecticide } & \multicolumn{4}{|c|}{ Week 5} & \multicolumn{4}{|c|}{ Week 6} & \multicolumn{4}{|c|}{ Week 7} \\
\hline & N1 & N2 & N3 & Mean & N1 & N2 & N3 & Mean & N1 & N2 & N3 & Mean \\
\hline L & 2.67 & 2.67 & 2.67 & 2.67 & 2.00 & 2.00 & 2.00 & 2.00 & 2.89 & 2.67 & 2.00 & 2.52 \\
\hline$P$ & 1.00 & 1.00 & 1.00 & 1.00 & 1.33 & 1.33 & 1.67 & 1.44 & 2.22 & 1.00 & 1.44 & 1.56 \\
\hline A & 2.67 & 2.67 & 2.67 & 2.67 & 2.00 & 2.00 & 2.00 & 2.00 & 2.67 & 2.67 & 2.00 & 2.44 \\
\hline 1 & 1.00 & 1.00 & 1.00 & 1.00 & 0.96 & 1.00 & 1.00 & 0.99 & 2.22 & 1.00 & 0.99 & 1.40 \\
\hline $\mathrm{C}$ & 3.00 & 2.67 & 2.67 & 2.78 & 2.00 & 2.33 & 2.33 & 2.22 & 3.11 & 2.78 & 2.22 & 2.70 \\
\hline Mean & $2.07 a$ & $2.00 a$ & $2.00 a$ & 2.02 & $1.66 a$ & $1.73 a$ & $1.80 \mathrm{a}$ & 1.73 & $2.62 \mathrm{a}$ & $2.02 \mathrm{a}$ & $1.73 a$ & 1.73 \\
\hline \multicolumn{13}{|c|}{ Season 2} \\
\hline \multirow{2}{*}{ Insecticide } & \multicolumn{4}{|c|}{ Week 5} & \multicolumn{4}{|c|}{ Week 6} & \multicolumn{4}{|c|}{ Week 7} \\
\hline & N1 & N2 & N3 & Mean & N1 & N2 & N3 & Mean & N1 & N2 & N3 & Mean \\
\hline$L$ & 3.33 & 2.67 & 3.33 & 3.11 & 3.33 & 3.67 & 3.67 & 3.56 & 3.33 & 3.11 & 3.56 & 3.33 \\
\hline$P$ & 2.67 & 1.67 & 2.00 & 2.11 & 1.73 & 0.67 & 1.67 & 1.36 & 2.11 & 2.11 & 1.36 & 1.86 \\
\hline A & 3.33 & 3.33 & 3.67 & 3.44 & 3.33 & 3.00 & 3.33 & 3.22 & 3.44 & 3.44 & 3.22 & 3.37 \\
\hline I & 2.67 & 2.00 & 2.67 & 2.44 & 1.67 & 1.67 & 2.33 & 1.89 & 2.67 & 2.44 & 1.89 & 2.33 \\
\hline$C$ & 4.00 & 3.33 & 3.33 & 3.56 & 4.33 & 3.67 & 3.33 & 3.78 & 4.78 & 3.56 & 3.78 & 4.04 \\
\hline Mean & $3.20 a$ & $2.60 a$ & $3.00 a$ & 2.93 & $2.88 a$ & $2.53 a$ & $2.87 a$ & 2.76 & $3.27 a$ & $2.93 a$ & $2.76 a$ & 2.99 \\
\hline
\end{tabular}

Table S4. Counts of Aenasius bambawalei (mealybug mummies) affected by nitrogen*insecticides.

\begin{tabular}{|c|c|c|c|c|c|c|c|c|c|c|c|c|}
\hline \multirow{2}{*}{ Insecticide } & \multicolumn{4}{|c|}{ Week 5} & \multicolumn{4}{|c|}{ Week 6} & \multicolumn{4}{|c|}{ Week 7} \\
\hline & N1 & N2 & N3 & Mean & N1 & N2 & N3 & Mean & N1 & N2 & N3 & Mean \\
\hline L & 0.79 & 0.75 & 0.77 & $0.77 a$ & 0.73 & 0.75 & 0.71 & $0.73 a b$ & 0.71 & 0.75 & 0.73 & $0.73 a$ \\
\hline$P$ & 0.77 & 0.77 & 0.75 & $0.76 a$ & 0.75 & 0.73 & 0.75 & $0.74 a$ & 0.73 & 0.73 & 0.71 & $0.72 a$ \\
\hline A & 0.77 & 0.77 & 0.82 & $0.79 a$ & 0.75 & 0.71 & 0.75 & $0.74 a$ & 0.73 & 0.73 & 0.71 & $0.72 a$ \\
\hline I & 0.75 & 0.79 & 0.75 & $0.76 a$ & 0.709 & 0.71 & 0.71 & $0.71 b$ & 0.75 & 0.71 & 0.71 & $0.72 a$ \\
\hline C & 0.79 & 0.79 & 0.77 & $0.79 a$ & 0.749 & 0.75 & 0.749 & $0.75 a$ & 0.73 & 0.73 & 0.77 & $0.74 a$ \\
\hline Mean & $0.78 a$ & $0.78 a$ & $0.77 a$ & 0.77 & $0.74 a$ & $0.73 a$ & $0.73 a$ & 0.73 & $0.73 a$ & $0.73 a$ & $0.73 a$ & 0.73 \\
\hline
\end{tabular}

No significant differences in all insecticides*nitrogen interaction means at 5\% probability. 
Table S5. Chrysoperla carnea analysis of variance summary containing the mean square (MS) for the 7 week counts in the two seasons.

\begin{tabular}{|c|c|c|c|c|c|c|c|c|c|c|c|c|c|c|c|}
\hline \multirow{2}{*}{ Source } & \multirow{2}{*}{ Df } & \multicolumn{7}{|c|}{ Season 1} & \multicolumn{7}{|c|}{ Season 3} \\
\hline & & W1 & W2 & W3 & W4 & W5 & W6 & W7 & W1 & W2 & W3 & W4 & W5 & W6 & W7 \\
\hline Replications & 2 & 0.29 & 2.07 & 1.76 & 2.29 & 2.47 & 0.62 & 0.69 & 0.33 & 1.76 & 1.76 & 1.99 & 3.25 & 1.95 & 3.69 \\
\hline Nitrogen & 2 & $0.6 \mathrm{~ns}$ & $0.47 \mathrm{~ns}$ & $0.29 \mathrm{~ns}$ & $2.96 \mathrm{~ns}$ & $6.20 \mathrm{~ns}$ & $2.69 \mathrm{~ns}$ & $1.09 \mathrm{~ns}$ & $0.65 \mathrm{~ns}$ & $0.29 \mathrm{~ns}$ & $0.08 \mathrm{~ns}$ & $1.20 \mathrm{~ns}$ & $4.53 \mathrm{~ns}$ & $5.40 \mathrm{~ns}$ & $5.15 \mathrm{~ns}$ \\
\hline Error 1 & 4 & 1.56 & 2.63 & 2.56 & 1.62 & 2.17 & 1.06 & 1.59 & 0.78 & 2.56 & 2.53 & 3.99 & 0.52 & 2.45 & 3.77 \\
\hline Insecticides & 4 & 0.5 & 1.03 & 1.24 & 3.48 & $6.19 * \star \star$ & $7.56^{\star \star *}$ & $12.2^{\star \star \star}$ & 0.19 & 1.19 & 0.97 & $2.81 \mathrm{~ns}$ & $9.86^{\star \star \star}$ & $4.94^{\star \star \star}$ & $8.76^{\star \star \star}$ \\
\hline $\begin{array}{l}\text { Nitrogen } x \\
\text { Insecticides }\end{array}$ & 8 & 0.3 & 1.80 & 1.84 & 1.43 & $0.59 \mathrm{~ns}$ & $0.61 \mathrm{~ns}$ & $1.17 \mathrm{~ns}$ & 0.35 & 1.87 & 1.70 & $0.68 \mathrm{~ns}$ & $0.42 \mathrm{~ns}$ & $0.45 \mathrm{~ns}$ & $0.70 \mathrm{~ns}$ \\
\hline Error 2 & 24 & 0.52 & 1.28 & 1.26 & 1.51 & 0.57 & 0.27 & 0.46 & 0.40 & 1.26 & 1.15 & 0.71 & 1.15 & 0.76 & 0.87 \\
\hline Total & 44 & - & - & - & - & - & - & - & - & - & - & - & - & - & - \\
\hline CV\% & - & 9.77 & 9.37 & 4.57 & 13.32 & 6.00 & 8.67 & 8.03 & 6.11 & 5.80 & 6.33 & 6.80 & 10.93 & 7.60 & 10.35 \\
\hline
\end{tabular}

*=significant at $5 \%$ probability. **=significant at $1 \%$ probability. ***=significant at $0.01 \%$ probability. ns=not significant.

Table S6. Aenasius bambawalei analysis of variance summary containing the mean square (MS) for the 7 week counts in season1.

\begin{tabular}{|c|c|c|c|c|c|c|c|c|}
\hline \multirow{2}{*}{ Source } & \multirow{2}{*}{ Df } & \multicolumn{7}{|c|}{ Season 1} \\
\hline & & W1 & W2 & W3 & W4 & W5 & W6 & W7 \\
\hline Replications & 2 & 0.00 & 0.003 & 0.003 & 0.005 & 0.000 & 0.003 & 0.000 \\
\hline Nitrogen & 2 & $0.00 \mathrm{~ns}$ & $0.001 \mathrm{~ns}$ & $0.001 \mathrm{~ns}$ & $0.001 \mathrm{~ns}$ & $0.000 \mathrm{~ns}$ & $0.000 \mathrm{~ns}$ & $0.000 \mathrm{~ns}$ \\
\hline Error 1 & 4 & 0.00 & 0.003 & 0.002 & 0.003 & 0.002 & 0.000 & 0.001 \\
\hline Insecticides & 4 & $0.00 \mathrm{~ns}$ & $0.001 \mathrm{~ns}$ & $0.003 \mathrm{~ns}$ & $0.004 \mathrm{~ns}$ & $0.001 \mathrm{~ns}$ & 0.002 * & $0.000 \mathrm{~ns}$ \\
\hline $\begin{array}{l}\text { Nitrogen } x \\
\text { Insecticides }\end{array}$ & 8 & $0.00 \mathrm{~ns}$ & $0.001 \mathrm{~ns}$ & $0.001 \mathrm{~ns}$ & $0.001 \mathrm{~ns}$ & $0.002 \mathrm{~ns}$ & $0.000 \mathrm{~ns}$ & $0.001 \mathrm{~ns}$ \\
\hline Error 2 & 24 & 0.00 & 0.001 & 0.002 & 0.002 & 0.002 & 0.000 & 0.000 \\
\hline Total & 44 & - & - & - & - & - & - & - \\
\hline CV\% & - & 0.00 & 6.80 & 5.95 & 6.33 & 5.00 & 7.17 & 4.43 \\
\hline
\end{tabular}

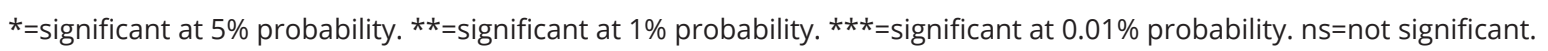

